\title{
Die daad onthul (im)moraliteit
}

\section{The deed reveals (im)morality}

\author{
Willem J Botha \\ Departement Afrikaans \\ Universiteit van Johannesburg \\ Suid-Afrika \\ E-pos: bothawil@gmail.com
}

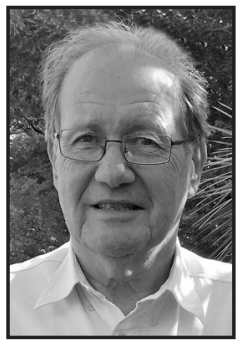

Willem Botha

Willem Botha se fokusgebiede binne die taalkunde is semantiek en sintaksis. Sy semantieknavorsing bedryf hy veral vanuit die raamwerk van die kognitiewe linguistiek. Hy was sedert die stigting van die International Cognitive Linguistics Association (ICLA) 'n lid daarvan, het baie jare lank aktief aan die bedrywighede van die vereniging deelgeneem en het by talle kongresse referate gelewer. Van sy navorsing is ook onder die vaandel van die betrokke vereniging internasionaal gepubliseer.
WiLlem ВотHA focusses his linguistic activities on semantics and syntax. His research in semantics is done mainly within the framework of cognitive linguistics. He has been a member of the International Cognitive Linguistics Association (ICLA) since its establishment, has for many years actively taken part in its activities and has read papers at numerous conferences. Many of his articles have been published internationally under the auspices of this association.

\section{ABSTRACT}

\section{The deed reveals (im)morality}

In the dramas of NP van Wyk Louw the deed manifests itself in different ways, which probably is the reason why most literary critics, after the publication of the drama Germanicus in 1956, considered the main character, Germanicus, to be very passive. Accordingly, the merits of the drama were called into question.

Their criticism centred on their judgement of the nature of the concept DEED (revealed as a derived noun deed from the verb to do). Traditionally, the meaning of the Afrikaans verb doen ("to do") is regarded to be so general that its meaning can be seen as "empty". The lexical item deed ("daad"), as a noun derived from the verb to do, can therefore be judged in a similar way. In this discussion, the semantic contents of the polysemous meanings of the noun deed are examined against the background of the drama Germanicus, which was created as a conceptual blend of three different historical sources and an imagined world.

A distinction is drawn between four different senses of the noun deed, typographically represented as deed ${ }^{\mathrm{a}}$ (referring to accomplished non-specific actions, frequently contrasted

\begin{tabular}{l} 
Datums: \\
Ontvang: 2019-08-20 Goedgekeur: 2020-01-30 $\quad$ Gepubliseer: Junie 2020 \\
\hline
\end{tabular}


with the lexical item word and with the implication of a result), deed ${ }^{\mathrm{b}}$ (referring to accomplished specific actions of force with a possible victim as a result), deed (vague non-specific physical, mental or other kinds of deed, actually denoting the concept [category] DEED) and deed ${ }^{\mathrm{d}}$ (metaphorical extensions of the lexical item deed).

Against the background of the drama Germanicus the different senses of the lexical item are exemplified. According to Langacker (1990:5), one of the foundational claims of cognitive semantics is that the meaning of an expression cannot be reduced to an objective characterisation of the situation described. For that reason, the conceptualiser chooses how to construe the situation and portray it. In the context of Germanicus different characters construe the concept DEED objectively, meaning that the lexical item deed is "salient by virtue of being placed onstage as the focus of attention" (Langacker 1990:7). In this regard it is shown that the sense of $\mathrm{deed}^{\mathrm{a}}$ as an accomplished non-specific action, contrasted with the lexical item word and with the implication of a result, occurs in many conversations, specifically when Germanicus is involved. The discussion furthermore discloses that the sense of $\mathrm{deed}^{\mathrm{b}}$ (referring to accomplished specific actions of force with possible victims as a result) is mostly construed subjectively and is implicit and non-salient in certain speech acts that refer to future acts expected from Germanicus. The use of the lexical item deed in its metaphorical use is also discussed.

In the discussion of the moral dimensions of the deed, the metaphor for morality is scrutinised. The moral conflict that Germanicus experiences with regard to the choices he has to make between two different kinds of expectations is viewed against the metaphor of morality. It is shown that the intricacies of instruments of the deed and moral justification, subjectively woven into the senses of specific explicit and implicit deeds, complicate the conceptualisation of the deed and morality - and in the context of the drama Germanicus they ultimately lead to the fatal choice that Germanicus makes/has to make.

Finally it is shown that the conceptual relationship of the concept DEED with other prominent concepts in the drama - concepts that are intimately linked to the experience of morality - in effect discloses a conceptual morality network within the drama. In view of this conceptual network of morality, and its intertwined relationship with different manifestations of the deed in the context of the drama Germanicus, it is concluded that Germanicus was not in any position to make a moral choice.

KEYWORDS: concept, deed, objective, subjective, morality, construal, blend, Germanicus, Tiberius

TREFWOORDE: konsep, daad, objektiewe, subjektiewe, moraliteit, konstruering, versmelting, Germanicus, Tiberius

\section{OPSOMMING}

Van Wyk Louw se dramatiese werk word gekenmerk deur verskillende manifestasies van die daad. Die betekenisonderskeidings van doen en daad in die genoemde werke het in die verlede egter tot aansienlike kontroversie aanleiding gegee, veral in die beoordeling van die versdrama Germanicus. Die karakter Germanicus is van sogenaamde daadloosheid beskuldig.

In hierdie bespreking word vier betekenisonderskeidings van die leksikale item daad binne die Germanicus-konteks ondersoek. Dit word gedoen teen die agtergrond van die feit dat dit verskillende manifestasies is van die konsep DAAD.

Uit die ontleding van die voorbeeldmateriaal uit Germanicus word aangetoon dat die betekenisnuanse "moraliteit" eksplisiet of implisiet deur sekere betekenisonderskeidings van daad "gedra" word. 
Uiteindelik dra die komplekse verweefdheid van daad en moraliteit daartoe by dat Germanicus nie in 'n posisie was om 'n morele keuse te maak nie.

\section{INLEIDING}

Van Wyk Louw se dramatiese werk word gekenmerk deur verskillende manifestasies van die daad. Sodanige uitspraak spreek eintlik vanself omdat die betekenis van die woord drama, soos afgelei uit Grieks, onder andere die volgende polisemiese betekenisonderskeidings het: "aksie", "daad", "spel”, "spektakel”, "doen" en "maak".

Die betekenisonderskeidings van doen en daad in die genoemde werke het in die verlede egter tot aansienlike kontroversie aanleiding gegee, veral in die beoordeling van die versdrama Germanicus. Die karakter Germanicus is van sogenaamde daadloosheid beskuldig.

Een van die prominentste uitsprake pas na die verskyning van die genoemde versdrama (in 1956) - en ook daarna - hou verband met Germanicus se beweerde daadloosheid. ${ }^{1}$ Grové (1965:74) praat van sy "gebrek aan optrede". Hy (ibid.:75) beskryf hom ook as "iemand wat kragtens sy hele menswees en binne die bepaalde omstandighede waarin hy hom bevind, nie anders as passief wíl wees nie." Van Heerden (1967:31) beweer selfs dat die "lang monoloë" ... "die handeling laat "stol"" as gevolg van die hoofkarakter se "basiese passiwiteit". Cloete (1980:4) verwys na aanleiding van Piso se aanklag teen Germanicus - "Dis ál wat ons nog uit jou kry: net woorde, / net praat en speel met moontlikheid" (Germanicus 1961:98) - dat in Van Wyk Louw se oeuvre "die intellektualisme of besinning die daad uitskakel." Conradie (1974:56) vind ' $n$ rede vir Germanicus se nie-optrede in die bewering dat hy sou vrees dat indien hy die mag sou gryp, "hy onvermydelik ook in die vuil van Rome ingetrek sou word, dat hy ook soos Tiberius sou word". Volgens Dekker (1963:366) weier Germanicus om 'n "aktiewe taak" te aanvaar in 'n wêreld waarin hy lotsverbonde is. Brink (1966:318) bring Germanicus se dadeloosheid (in ooreenstemming met dié van Hamlet en Antony) in verband met die feit dat hy nie "skeppend (kan) optree teenoor die chaos nie" omdat hy "in sy hoogste ideaal ... onwetend ... onsuiwer is", gemotiveer deur Germanicus se uiteindelike besef: “"n Mens die moet ook modderig wees / as jy wil mens-wees - óf as jy wil heers ..." (Germanicus 1961:109).

Antonissen (1963:180) verskil egter radikaal van sodanige uitsprake wat volgens hom berus op idées fixes met betrekking tot die begrippe "tragiek", "tragedie", "daad-handeling" en selfs "drama". Hy (ibid.:181) stel dit onomwonde dat Germanicus "volstrek nie 'passief" is nie en hom ook nie passief gedra nie" - en sê verder: "Dink of heilige-wees of strewe-naheiligheid is nie passief nie, maar hoogste menslike aktiwiteit." Sou Austin (1962) se baanbrekerswerk oor die aard van taalhandelinge in hierdie tyd reeds algemeen bekend gewees het, sou hy kon byvoeg dat taal meer doen as net om te verwys - dat taal in der waarheid self daad is en dat deur taaldade die wêreld verander (kan) word. ${ }^{2}$ Dit is reeds vanuit so 'n

\footnotetext{
$1 \quad$ Waarskynlik was die kritici onbewus van 'n uitspraak wat Van Wyk Louw reeds in 1952 gemaak het oor die diep betekenis van die woord daad in 'n opstel "Kultuur en krisis", in "Liberale nasionalisme", soos opgeneem in Versamelde prosa 1. Andersins het hulle dié uitspraak nie ernstig bejeën nie. Ek bedank prof. Jaap Steyn vir die feit dat hy hierdie en ander Van Wyk Louw-uitsprake oor die daad onder my aandag gebring het.

2 In die voorgenoemde opstel ("Kultuur en krisis") het Louw in 1952 juis ook die uitspraak gemaak dat die woord self ook 'n daad is. Prof. Jaap Steyn wys my daarop dat Reichling in sy opstel "De Taal: haar wetten en haar wezen" reeds in die jare veertig daarop gewys het dat taal 'n handeling is: "(M)ijn spreken is zelf ook een handeling. Het is een handeling van een bijzonder soort" - vergelyk https://www.ensie.nl/ensie-1947/taal-haar-wetten-en-haar-wezen.
} 
benadering dat Botha (1991:28) die sekwensie van enkele van die dominante makrotaalhandelinge in die dramatiese verloop van Germanicus onderskei: DIREKTIEWE (eise en dreigemente gerig tot Germanicus) > GESAGSHANDELING (Germanicus se implisiete weiering) $>$ andermaal 'n DIREKTIEF (Germanicus se versoek tot Tiberius om hom te verlos van die "swaar las van moet-heers") > weer 'n GESAGSHANDELING (Tiberius se weiering van Germanicus se versoek) > VERBINTENISHANDELING (Germanicus se aanvaarding van sy lot soos hy "ook die dood aanvaar"). ${ }^{3}$

Een van die belangrikste redes wat moontlik aanleiding kon gegee het tot die krasse veroordeling van Germanicus se doenhandelinge (of liewer nié-doenhandelinge) is waarskynlik geleë in die feit dat die woord $\mathrm{daad}^{4}$ so 'n wye semantiese spektrum van doenhandelinge impliseer. Dit sal dus eerstens nodig wees om die semantiek van die woord daad (as afgeleide selfstandige naamwoord van die werkwoord doen) te ondersoek.

Onder die oppervlak van die doenhandelinge in Van Wyk Louw se dramatiese werk - en heg verweef daarmee - lê die intensie, die strategieë en die dramatiese krag van die handelinge as implisiete (soms ook eksplisiete) vergestalting van morele oordeel en optrede.

$\mathrm{Na}$ 'n ontleding van die semantiese verhouding tussen die werkwoord doen en die selfstandige naamwoord daad, sal in hierdie betoog die betekenisonderskeidings wat deur die substantief daad gedra word, aan bod kom. Daarna sal die morele dimensie van die daad onder die loep kom. Die versdrama Germanicus sal die hooffokus van hierdie bespreking wees. Van die argumente in hierdie betoog sal ook getoets kan word in ander dramatiese werke deur Van Wyk Louw, onder andere Die held, Dias en die epiese gedig Raka.

Hierdie artikel is gebaseer op die volgende publikasies en ongepubliseerde materiaal deur die onderhawige outeur: Botha (1991), Botha (2006), Botha (2009a), Botha (2009b).

\section{SEMANTIEK VAN DIE WOORD DAAD}

\section{Doen en die daad}

Botha (2009a:182) noem dat die substantief daad in 'n afgeleide verhouding staan tot die werkwoord doen. Ek wys daarop dat in albei gevalle die verwysingspektrum van die betrokke twee leksikale items só omvangryk is dat daar dikwels in die literatuur na hulle semantiese inhoud as sogenaamd "leeg" verwys word (vergelyk Botha (1975) en Ponelis (1978:208, 210, 427 ) ten opsigte van die werkwoord doen). Dit sou natuurlik 'n oorveralgemening wees juis omdat hierdie woorde meermale op 'n superordinaatvlak sodanig funksioneer dat dit die spreker in staat stel om betekenisnuanserend meer algemeen te verwys (dus: 'n betekenisstrategie), in teenstelling met hulle hiponieme wat meer spesifieke verwysing tot gevolg het. Piso gebruik byvoorbeeld die superordinaatwerkwoord vernietig ten opsigte van die eis aan Germanicus met betrekking tot Tiberius se verwagte lot aan die hand van Germanicus, in plaas van die hiponiemwerkwoord doodmaak, die waarskynlike daad wat geïmpliseer word binne die betrokke konteks: "Dat jy Tiberius slaan en hom vernietig - " (Germanicus 1961:100). Ten opsigte van die verskillende hiërargiese vlakke waarbinne hierdie werkwoord (vernietig)

Vergelyk Botha (1991:28) vir tersaaklike voorbeelde uit die teks ter illustrasie.

Alhoewel daar in hierdie betoog klem gelê word op die woordstatus van daad, moet in gedagte gehou word dat die woord eintlik net neerslag is van die konsep DAAD, en dat die konsep se betekenis veel meer inhou as net die poliseme en semantiese betrekkinge wat woordbetekenis bepaal. Waar daar wel sprake van die konsepstatus is, sal die betrokke konsep in KLEIN-HOOFLETTERS voorgestel word. Woordstatus sal in kursief aangedui word. 
semanties funksioneer, sal op 'n skaal van meer abstrak (algemeen) tot minder abstrak (dus meer spesifiek) - binne die betrokke konteks - vernietig waarskynlik op 'n intermediêre vlak lê: doen (dus 'n daad) > vernietig $>$ doodmaak $>$ (moontlik) vermoor. Die prototipiese betekenis van doen is "handeling".

Die verskillende betekenisonderskeidings van doen hang grootliks saam met die sintaktiese en gepaardgaande semantiese omgewings waarbinne die betrokke werkwoord hom bevind. Daarenteen word daad se betekenisonderskeidings hoofsaaklik deur die betrokke gebruikskonteks bepaal - synde 'n verwysing na:

- afgeslote, ongespesifiseerde fisiese handelinge, gewoonlik gekontrasteer met die leksikale item woord, en met die implikasie van 'n resultaat tot gevolg, in hierdie artikel weergegee as daad $^{\mathrm{a}}$;

- afgeslote gespesifiseerde soorte fisiese handelinge wat met geweld gepaard mag gaan en 'n slagoffer as resultaat mag hê, weergegee as $d a a d^{\mathrm{b}}$;

- vae, ongespesifiseerde fisiese, psigiese of ander soorte dade - dus eintlik na die konsep $^{5}$ (kategorie) DAAD, in hierdie konteks voorgestel deur die leksikale item daad ;

- metaforiese uitbreidings van die leksikale item daad, na verwys as daad $^{\mathrm{d}}$.

In die voorgaande semantiese klassifikasie van die betrokke leksikale item is daar in twee gevalle gewys op die feit dat die betekenisonderskeiding "resultaat" by die betekenis van daad ingebed is. Nie alle doen-handelinge is/word egter dade nie, veral wanneer statief-werkwoorde (nie-handelingswerkwoorde) ter sprake is. Dit berus dikwels by die oordeel van die spreker of hy/sy ' $n$ bepaalde handeling inderdaad as 'n daad sou wou benoem, soos byvoorbeeld ook by die seleksie van afgeleide naamwoorde soos wandaad, weldaad, misdaad, ensovoorts om bepaalde afgeslote handelinge te beskryf. Ons sou in sodanige gevalle van "oordeelsnaamwoorde" kon praat, in ooreenstemming met die term "oordeelsadjunk" wat Ponelis (1978:309) gebruik om onder andere adjektiewe te beskryf waarvan die seleksie bepaal word deur die oordeel van die spreker.

Binne die Germanicus-konteks, waar die substantief daad nie eksplisiet genoem word nie en handelinge plaasvind wat as dade benoem sou kon word, berus die identifikasie van die aard van die besondere daad by die karakters in die drama (en natuurlik die leser/hoorder). Kontekstuele faktore sou as leidrade kon dien vir die betrokke benoeming.

\section{Konteks en die daad}

Conradie (1974) wys daarop dat Louw vanuit veral drie bronne die geskiedenis verwoord het, gewysig het en herrangskik het tot die drama Germanicus. Dit vorm ook deel van die kennisdomein ('n "more generalized 'background' knowledge configuration" - vergelyk Taylor 2002:195) wat saamgelees behoort te word met die konteks wat binne die betrokke drama geskep word, dus die spesifieke historiese omstandighede waarbinne die drama Germanicus gesitueer is: 'n tyd (dus: konteks) van opstand, geweld, veldslae en selfs moord - 'n tyd waarin die fisiese daad 'n belangrike beslegtingsmeganisme was.

Sodanige agtergrond-kennisdomein word saamgevat in Tiberius se woorde - ook 'n implisiete verwysing na die immoraliteit van die bepaalde tydsgewrig: "Ons is gebind / aan

Taylor (2002:193) beskryf die begrip "konsep" as die beginsel op grond waarvan kategorisering kan plaasvind, wat beteken dat ' $n$ konsep ons in staat stel om verskillende voorbeelde daarvan te herken - op grond waarvan talige benoeming plaasvind. 
die lot in die stink kloaak van hierdie Ryk, / en die vuil van hierdie tyd spoel oor ons almal" (Germanicus 1961:74). Sodanige konteks bring noodwendig mee dat die aard van die fisiese daad dikwels verskillende vorme aanneem. Daarom bly die woord daad in baie verwysings ongedefinieer en is slegs af te lei uit die aard van die betrokke handeling. Waar die woord daad gebruik word in besinning oor die daad, word dit binne die besondere konteks as 'n ontologiese metafoor ${ }^{6}$ gebruik. $^{2}$

Germanicus motiveer dié status wanneer hy aan Piso sê: "Maar áls is ingewikkeld; selfs die daad / is nie, soos jy meen, enkeld" (Germanicus 1961:100). Met hierdie uitspraak transponeer hy die betekenisinhoud van die woord daad egter na 'n abstrakter konseptuele hiërargiese vlak ${ }^{7}\left(\right.$ daad $\left.^{\mathrm{d}}\right)$. En Piso se verwyt teenoor Germanicus, naamlik "Dis ál wat ons nog uit jou kry: net woorde" (Germanicus 1961:98) - dus (geïmpliseer) nie dade nie - reflekteer die betekenisinhoud van daad op die vlak van daad $^{\text {a }}$, terwyl hy eintlik suggereer, teen die agtergrond van die drama, dat sy verwagting is dat Germanicus die daad op die hiërargiese vlak wat deur $\mathrm{daad}^{\mathrm{b}}$ weerspieël word, moet pleeg. Die suggestie van die betekenisonderskeiding van $d a a d^{b}$ is ook opgesluit in talle ander verwysings na die ongedefinieerde daad $\left(\right.$ daad $\left.^{\mathrm{c}}\right)$.

\section{Geobjektiveerde dade}

Binne die Germanicus-konteks word dade geobjektiveer ${ }^{8}$ wanneer oor dade besin word, maar dade word ook gesuggereer en ook geïmpliseer deur bepaalde handelinge van die onderskeie karakters. In die geval van gesuggereerde en geïmpliseerde dade sou daar sprake kon wees van gesubjektiveerde konstruering. Dit berus dan gewoonlik by die leser/hoorder (interpreteerder) om die aard van die daad te herken en te identifiseer - en in die drama hang dit ook grootliks saam met die herkenning en identifisering van die aard van die spesifieke taalhandelinge.

Binne die Germanicus-konteks besin verskillende karakters oor die aard van die daad wat dit 'n wesenlike geobjektiveerde ervaring maak. Enersyds bring Lucius byvoorbeeld die daad in verband met opstand, iets "waarna ons hele lewe uitgereik het / soos na geen vrou" (Germanicus 1961:20); andersyds bring sy twyfel en vertwyfeling vir hom die doodsdrif as alternatief daarvoor in die woorde: "hoe nederig is die daad, hoe groots die dood" (Germanicus

6 Ontologiese metafore stel ons in staat om sintakties (byvoorbeeld as naamwoordstukke) en andersins na abstraksies te verwys asof dit konkrete dinge sou voorstel, byvoorbeeld die daad. So vind ons ook ontologiese metafore in Tiberius se woorde: “... die vuil van hierdie tyd spoel oor ons almal" (Germanicus 1961:74). Volgens Lakoff en Johnson (1980:26) stel ontologiese metafore ons in staat "to refer to it, quantify it, identify a particular aspect of it, see it as a cause, act with respect to it, and perhaps even believe that we understand it".

7 Die verskillende betekenisonderskeidings van daad staan ook in 'n superordinaat-hiponiemverhouding tot mekaar, 'n hiërargiese betekenisstruktuur wat die kompleksiteit van die betekenis van die betrokke leksikale item verhoog - 'n aspek wat nie verder in hierdie oorsig aandag sal geniet nie. Vergelyk Botha (2006).

$8 \quad$ Langacker (1990:7) gebruik die terme "geobjektiveerde" en "gesubjektiveerde konstruering" om aan te dui dat 'n "entity construed subjectively is implicit and hence non-salient ... whereas the objectively-construed entity is salient by virtue of being placed onstage as the focus of attention". Hy benadruk die feit dat die genoemde twee terme en hulle afleidings in 'n spesiale, tegniese betekenis gebruik word, en alhoewel hulle betekenisse verwant is aan die konvensionele gebruik van die terme 'objektief' en 'subjektief', hulle nie ekwivalent daaraan gebruik word nie. Van Wyk Louw se eie besinning oor die daad in die1952-opstel, waarna vroeër verwys is, getuig ook van 'n geobjektiveerde betekeniskonstruering. 
1961:26). Germanicus se versugting na die daad vind ons in sy eie woorde: "Het ek nie daad, oorwinning, eer, mag / soos drank voel opstoot deur my sinne nie / en droë-keel geword van die begeerte / meer as een dag!" (Germanicus 1961:33); maar ook sy twyfel daaroor wanneer hy in Lucius se dood laasgenoemde verlos sien daarvan, en opmerk: "Waarom spring ons van dag tot dag van daad / na daad?” (Germanicus 1961:41).

In die voorgaande voorbeelde word die leksikale item daad gebruik om veral na die kategorie (konsep) DAAD te verwys; dus voorbeelde van daad $^{c}$.

\section{Daad as 'n fisiese handeling met slagoffers as resultaat}

Binne die betrokke dramakonteks konstitueer daad 'n betekenisinhoud van die woord wat neerkom op verskillende manifestasies van geweld met die noodwendige implikasie van 'n slagoffer - soos met Germanicus se neersteek van die soldaat, die foltering en waarskynlike dood van die slaaf Clemens, en ook Livia se vernedering van die gevangene Thusnelda. En die kulminasie van geweldpleging deur die daad word gesuggereer deur Tiberius se (immorele) verwysing na mense as "buit"; mense ook geïmpliseer in sy "moeras"-metafoor: "'n goor welsel uit die aarde / wat uit 'n honderd gate en skeure borrel" (Germanicus 1961:71). Word die daad aan slagoffers gemeet, dan is Tiberius waarskynlik die beste eksponent van die daad in hierdie drama. Dit is ook insiggewend dat Piso se enigste (implisiete) geweld-daad (daad $\left.{ }^{b}\right)$ sy aandeel aan Germanicus se vergiftiging is - andersins tree hy taalhandelend op, sonder eksplisiete verwysing na die daad maar deur die gebruik van doen-frases wat die betekenisonderskeiding van $\mathrm{daad}^{\mathrm{b}}$ suggereer, wanneer hy byvoorbeeld van Germanicus eis ("Die man wat heers in Rome, moet hier heers" - Germanicus 1961:12), wanneer hy Germanicus dreig ("en wie óns - ek en julle - nie vertrou nie, / wip gouer uit die saal as hy geklim het" - Germanicus 1961:12), wanneer hy oprui en aanstig ("(V)annag het iets by ons gebreek. / ... / van nou af sal ons een-een dalk moet handel. / Word hy 'n Caesar, staan ons weer teen hóm" - Germanicus 1961:22), en wanneer hy sy ontrouheid rugbaar maak in sy eis dat Germanicus Tiberius moet vernietig. In hierdie gevalle bepaal die aard van die taalhandelinge die aard van die dade.

Dit is betekenisvol - miskien ook ironies - dat, ten spyte van die verwyt van dadeloosheid, $d a a d^{b}$ tog ook die vlak is waarop Germanicus verskillende dade vergestalt, byvoorbeeld in die veldslag teen die Cheruskers. Die jong offisier rapporteer die geweld daarvan as 'n "jag ... op ménse; na die oë slaan / wat wit en bewerig smeek, en wéér en wéér / die swaard voel ínsink ...” (Germanicus 1961:34), en hy verhaal ook Germanicus se optrede tydens die slag toe hy "sy helm weggesmyt (het) en oop / - soos 'n god - " (Germanicus 1961:36) sy manskappe aangevoer het. Germanicus word verder ook eksplisiete eksponent van die daad van geweld met die neersteek van die soldaat om die eer van Julia te beskerm met die veelseggende woordkeuse "offer" in "Dis ek wat hierdie offer slag" (Germanicus 1961:14).

Nieteenstaande Germanicus se gewelddadige optrede, soos hier bo na verwys, en ook die geweldpleging deur ander karakters, is die verwagting dat die betekenisinhoud van daad $^{\mathrm{b}}$ vir Germanicus gerig moet wees op 'n spesifieke slagoffer. Die status van die daad, soos van Germanicus vereis, word dus bepaal deur die identiteit van die slagoffer. Daarom hef 'n daad van geweld teen onbekende of mindere slagoffers nie sy beweerde dadeloosheid op nie. Die daad moet vereenduidig word op grond van die persoon van die slagoffer, soos uitgespel in Piso se eis: "Dat jy Tiberius slaan en hom vernietig - " (Germanicus 1961:100). 


\section{Versmelting van betekenisonderskeidings}

Metaforiese verbandlegging (ook versmelting genoem - "blending") geskied op grond van die kartering van ensiklopediese kennis ${ }^{9}$ van 'n minder abstrakte denkruimte na 'n abstrakter denkruimte. Op grond daarvan word die nuwe denkruimte, die denkruimte waarin die metafoor verstaan word, die resultaat van die genoemde versmelting. Die betekenis van die metafoor is in die versmelte denkruimte te vind.

Binne die Germanicus-konteks is dit juis die gewelddaad, as konkrete handeling, wat as die invoerdomein (denkruimte) vir versmelting dien om oor die daad op 'n hoër en abstrakter vlak te besin. Daarom verwys Germanicus na die daad as nie "enkeld” nie! Sodanige verwysing impliseer dan juis 'n abstrakter vlak van handeling, soos verteenwoordig deur daad . Hierdie handelingsvlak laat juis toe dat die daad verskillende geaardhede en variasies kan hê. Dit bied meer beweegruimte binne die grense van die daad. Dit is op hierdie vlak wat Germanicus sy eie lot "kragdadig" verseël met die woorde aan Tiberius: "Ek neem dit aan. / Ek vat dit soos ek ook die dood aanvaar / en al wat menslik is" (Germanicus 1961:84). Germanicus se woorde (verbintenis-taalhandeling) word die vergestalting van 'n (self)vernietigingsdaad as (versweë) konseptuele metafoor: die dood. Anders gestel: Germanicus verbind hom tot die dood.

Maar die verwysing na die nie-enkeldheid van die daad impliseer dat dit ook verwys na iets wat verknoop is met die daad in al sy manifestasies. Germanicus motiveer die nieenkeldheid daarvan self as iets wat nie rasioneel agterhaalbaar is nie: "selfs die daad / is nie, ..., enkeld; en die denk / sit knoop aan knoop gekoek" (Germanicus 1961:100); ook in nog woorde aan Piso: "Vir jou is alles enkeld; en vir my / ... veelvuldig alles, / en eindeloos vol spel en moontlikheid" (Germanicus 1961:97/98). Dit sou nie vergesog wees om te vermoed nie dat Germanicus hier ook die kompleksiteit van die oorsprong van die daad in gedagte gehad het (verder terug as die intensie) - die rasionaal agter wat hom "al wat menslik is" laat aanvaar het - dus 'n morele oordeel!

Daar bestaan geen absolute grense tussen die verskillende betekenisonderskeidings van die woord daad binne die Germanicus-konteks nie. Dit kan onder andere toegeskryf word aan die feit dat betekenisonderskeidings ineenvloeiend (versmeltend) is, dat die konteks bepaalde (eksplisiete) betekenisonderskeidings konstitueer, dat subtiele onderskeidings berus by die oordeel van die interpreteerder, wat faktore soos beheersende punt en die "ensiklopediese kennis" van die interpreteerder insluit. Hierby kan toegevoeg word dat daar ook "immanente" betekenisnuanses binne die konseptuele omvang van die konsep DAAD bestaan, soos byvoorbeeld morele oordeel. Langacker (2004:309) beweer dat selfs by geobjektiveerde konstruering (dus besinning oor die daad) "the subjectively construed elements were there all along, 'immanent' in the very act of conceptualizing the objectively construed element". Die onderskeie karakters (binne die Germanicus-konteks) se verskillende vertolkings van die woordbetekenis van daad (én van daad-handelinge) illustreer juis sodanige kompleksiteit van die betrokke konsep. Daad word dan as 'n eksplisiete of implisiete oordeelsnaamwoord ervaar, ten opsigte waarvan 'n gesubjektiveerde betekenismoment "moraliteit" binne die bepaalde konteks sy weg na die voorgrond vind.

Vervolgens word die moraliteitsdimensie van die daad onder die loep geneem.

9 “(A) structured system of knowledge, organised as a network”(vergelyk Evans \& Green 2006:216). 


\section{DIE MORELE DIMENSIE VAN DIE DAAD}

\section{Die moraliteitsmetafoor}

In ooreenstemming met die mens se beliggaamde ervaring ${ }^{10}$ van die werklikheid en abstraksies gebaseer op sodanige ervarings is een van die mees basiese konseptuele metafore op grond waarvan moraliteit verstaan word, die sogenaamde "moral accounting"-metafoor - waarvan die uitdrukkings morele bankrotskap en die Engelse moral accountability byvoorbeeld manifestasies is. Hierdie uitdrukkings is by implikasie die manifestasie van 'n aantal basiese ervaringskemas (veral die ewewigskema) op grond waarvan die metafoor "die morele boeke balanseer" verstaan word.

Lakoff en Johnson (1999:293-298) onderskei onder andere die volgende skemas wat die betrokke metafoor onderlê: morele wisselwerking, retribusie/vergelding, restitusie, altruïsme, die-ander-wang-draai-ervaring, karma en billikheid. Morele gedrag, deur watter skema ook al talig gerealiseer in die betekenis van die metafoor "die morele boeke balanseer", word deur twee beginsels onderlê (volgens die genoemde outeurs), naamlik:

- Morele optrede veronderstel die gee van iets met positiewe waarde, terwyl immorele optrede die gee van iets met 'n negatiewe waarde impliseer.

- Morele optrede vooronderstel dat morele skuld vereffen sal word, terwyl immorele optrede die ontduiking van morele skuld impliseer.

Teen hierdie agtergrond is die morele problematiek baie kompleks wanneer Germanicus voor die morele keuse gestel word om te kies: immorele optrede teenoor Tiberius, ter wille van 'n morele verpligting teenoor die volk, óf immorele optrede teenoor die volk (gevolglik moreel teenoor Tiberius) in die naam van moraliteit, om die immoraliteit van verraad te ontduik - in sy eie woorde: "Ek is getrou. Ek is aan trou gewoond" (Germanicus 1961:9). Germanicus kan immoraliteit nie ontsnap nie - hy kan die morele boeke nie laat klop nie!

Germanicus se (im)moraliteit is verknoop aan die daad (en sogenaamde nie-daad) in al sy manifestasies: geobjektiveer, gesubjektiveer of as immanente betekenisnuanse binne die konsep DAAD.

Etlike implikasies van hierdie moraliteitsbeskouing word vervolgens onder die loep geneem.

Soos reeds aangedui, is mense slagoffers ${ }^{11}$ van die daad $\left(\right.$ daad $\left.^{b}\right)$ in hierdie drama. Dié metafoor (slagoffers) word bykans verletterlik in Germanicus se woorde: "Dis ek wat hierdie offer slag" (Germanicus 1961:14). Die demonstratief hierdie binne die naamwoordstuk hierdie offer impliseer juis dat daar meerdere offers is - en daar is wel. Die bestek van hierdie bespreking laat nie 'n volledige opgaaf toe nie. Eksemplaries is daar reeds na enkele van Germanicus se dade binne hierdie betekenisonderskeiding verwys. Vervolgens word die aandag gewy aan die betekenisonderskeiding "instrument van die daad" (aanvullend tot "slagoffer

10 Johnson (1987:xiii) wys daarop dat ons begrip van die wêreld onderlê word deur 'n beliggaamde struktuur en 'n verbeeldingstruktuur, wat daarop neerkom dat ons abstraksies modelleer op grond van ons liggaamlike ervaring van die werklikheid in terme van 'n verbeeldingstruktuur wat saamgestel is uit beeldskematiese strukture.

11 Verklarende Afrikaanse woordeboek se betekenisbeskrywing van die metaforiese gebruik van die woord slagoffer verwys tereg na iemand wat "vernietig word of ly as gevolg van 'n gewelddaad". 
van die daad") wat latent is binne die betekenisbestek van daad $^{\text {b }}$. Verskillende instrumente van die daad kan ook heelwat uiteenlopende morele implikasies hê-veral vanuit die onderskeie beheersende punte van verskillende karakters.

\section{Instrumente van die daad}

In die veldtogte wat Germanicus onderneem - waarvan Louw net een kies om 'n hele kampanje te verteenwoordig, aldus Conradie (1974:42) - verloor onbekende slagoffers hulle lewens. Hierin tree Germanicus as instrument van die daad op. Die aard van dié daad beskryf hy self as "die swaar Ryk" wat "máál ... en bréék", en hy sien homself as "die krag / wat op die ver uithoek hierdie werk" vir die Ryk doen, en besef: "hy [die Ryk] kon ook ander kragte / en ander hande vir sy duister arbeid / vind - en báie maal - ook sonder my" (Germanicus 1961:46). Germanicus se verwysing na "duister arbeid" suggereer sy vertwyfeling in die moraliteit van sy plig as soldaat en veldheer. Wanneer hy in desperaatheid teenoor Tiberius uitroep dat hy gru, dat hy vrees dat die Ryk hom “ook sal gryp / en ánders maak ... en minder ...” (Germanicus 1961:74), in reaksie op Tiberius se minagting van die mens, wanhoop hy reeds aan die moraliteit van sy dade as soldaat. Uiteindelik kom hy tot die besef dat die omstandighede van die Ryk wat "met sy fondamente in die klei / van die haat en bitterheid" lê (Germanicus 1961:80), sy eie "bloedige ambag" (dus: daad $^{\text {b) }}$ as soldaat sinneloos maak. Die relaas van die jong offisier van die vroeëre veldslag as 'n jag “op ménse; na die oë slaan / wat wit en bewerig smeek" (Germanicus 1961:34), eggo, in ooreenstemming met Tiberius se minagting van die mensheid, die immoraliteit van die oorlogsdaad. Hierdie beskrywing beeld nie die vyand of teenstanders uit nie. Dit is 'n beskrywing van slagoffers.

Germanicus kan die metafoor van die Ryk nie ontsnap nie! Tiberius versmelt hom dienooreenkomstig in die "swart donker dier wat skuil", waarvan Tiberius "die kop" en Germanicus "die klou” is, en kom tot die gevolgtrekking: "Elkeen doen maar sy werk: jy, skoon; ek, vuil ..." (Germanicus 1961:82). Die substantief werk is 'n spesifikasie van die doen (dus: die daad) waarvan Tiberius praat, maar werk as sodanig dra 'n verpligting in hom opgesluit - en dit is hierdie verpligting aan die Ryk wat Germanicus, nieteenstaande die wyse waarop hy instrument is, nie kan ontsnap nie. Dit bring die moraliteit van Germanicus se dade (in die betekenis van daad $^{b}$ ) vir die Ryk onder verdenking.

'n Variasie van die klou-metafoor word gevind in die woord hande - as metafoor of binne metafore gebruik. Dit is dus nie vreemd nie dat hande, as tipiese instrumente van die fisiese daad, redelik frekwent in die betrokke drama voorkom. Wat in hierdie verband egter belangrik is, is die feit dat hierdie metafore draers word van verskillende morele dimensies van die daad.

Na die veldslag waarna die jong offisier verwys as die “jag ... op ménse”, veredel Agrippina byvoorbeeld die daad $\left(\right.$ daad $\left.^{b}\right)$ met die "dapper hande" (instrumente van geweld) van die soldate wat sy wil vat (Germanicus 1961:38). Daarteenoor verteenwoordig Tiberius se verwysing na "Caesar se vuil hande" (Germanicus 1961:74) 'n aanklag teen sy eie immoraliteit. Dit is insiggewend dat die verwysing na homself in hierdie verband in die derde persoon geskied. Onttrekking uit die deiktiese sentrum (distansiëring) word hier'n ontsnapping van aanvaarding deur die self. Maar hande se metaforiese nuanses kry ook in Tiberius anders beslag wanneer hy tog verwys na "my eie hande is swart en eensaam voor my / waar ek tas" (Germanicus 1961:80). Hierdie verwyt teen immoraliteit kan juis nie anders as op die self gerig wees nie - ook omdat dit gepaard gaan met 'n verwysing na 'n vernietigende emosionele gesteldheid (eensaamheid) wat die gevolg is van sy immoraliteit. Feitlik onmiddellik daarna onttrek hy die self weer uit die deiktiese sentrum met die derdepersoonsopmerking: "Dis werk vir die 
aasvoël, vir Tiberius" (Germanicus 1961:80). Germanicus verwoord hierdie morele ambivalensie van Tiberius wanneer hy hom waarsku "jy gryp / met hande wat nie joune is, na mense, / ... dit kom uit die waansin" (Germanicus 1961:83).

'n Volledige bespreking van al die instrumente van die daad val buite hierdie bestek.

Daar dien egter nog op gelet te word, teen die agtergrond van die voorgaande bespreking, dat die metafoor (vir die instrument van die daad, óf die daad self, óf die slagoffer van die daad) immoraliteit kan kondoneer. In hierdie opsig hang die moraliteitservaring saam met die beheersende punt waaruit dit beoordeel word. Daar is reeds gewys op Tiberius se onttrekking uit die deiktiese sentrum om die immorele aanslag gedeeltelik af te weer. Maar dan is daar ook verwysings na "die dooies" wat soos "koringstingels" lê (Germanicus 1961:37) - in plaas van "slagoffers"; Tiberius se verwysing na mense as "buit" (Germanicus 1961:71), waarin die metafoor hom moet ontdaan van enige gevoel van menslikheid; en Germanicus se verwysing

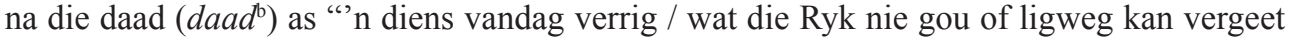
nie". Hierdie verskynsel, waarin immoraliteit deur die metafoor verbloem word, kulmineer in die metafoor wat Germanicus teenoor Piso gebruik as laasgenoemde homself identifiseer as "Romein, soldaat en offisier" (Germanicus 1961:42), iemand wat sy plig ken en dit doen. Dít - die ontduiking van die waarskynlike woord slagoffer - antwoord hy op die vraag "Wat sien jy as jy steek?" (Germanicus 1961:41), waarop Germanicus die aard van moraliteitsverhulling saamvat in: "Dis vreemd dat woorde so 'n kors kan maak / rondom die hart. Nooit raak mens aan die lewe / wat fyn en bewerig soos 'n kindjie sit nie" (Germanicus 1961:42). Hierin suggereer Germanicus ook sy eie morele bedenkinge ten opsigte van die oorlogsdaad.

Moraliteit betrek egter nie net die daad $\left(\right.$ daad $\left.^{\mathrm{b}}\right)$ self en die fisiese omstandighede van die daad nie. Dit lê ook op 'n hoër en abstrakter vlak, wanneer die daad besinning en woorde word - die vlak van morele regverdiging.

\section{Morele regverdiging}

Alhoewel Germanicus as soldaat binne die dade van geweld $\left(\right.$ daad $\left.^{\mathrm{b}}\right)$ - en dus die dampkring van immoraliteit - funksioneer, is die morele impak daarvan gering in vergelyking met sy immoraliteit wat daarin geleë is dat hy "nie gróót wou wees" nie maar "gewoon was" (Germanicus 1961:112); dat hulle van hom geglo het "dat hy die Caesar-wortel uit sou grawe" (Germanicus 1961:22), en hy hét nie - al hierdie bewerings deur Piso; en verder dat hy Piso se liefde wat hom verbind het aan "áls / wat enkeld suiwer was" (Germanicus 1961:112), beskaam het. Vir Piso sou dié suiwerheid gestalte kry in die motief vir Tiberius se vernietiging, naamlik die herstel van die Ryk wat spruit uit 'n lojaliteit aan die Ryk.

Maar dit is júis Germanicus se suiwerheid wat hom nie toelaat om Tiberius te vernietig nie, wat hom laat besef: "Ek was te helder. / 'n Mens die moet ook modderig wees / as jy wil mens-wees - óf as jy wil heers ..." (Germanicus 1961:109). Germanicus is vasgevang in 'n kragveld wat gekonstitueer word deur "moral reasoning" en "moral behaviour"12 In teenstelling met Piso, wat ooreenkomstig "morality of constraint", ... "of duty pure and simple" (Westen 1996:558) optree, beredeneer Germanicus die morele implikasies van sy moontlike daadkeuses. Binne hierdie verband gaan hy selfs so ver om binne die model van "morality of cooperation" (Westen 1996:558), waarbinne morele reëls verander kan word, tevergeefs Tiberius tot ander morele insigte te bring met die woorde: "maar ek tas ... na 'n helderheid, /

12 Vergelyk Westen (1996:557 e.v.) ten opsigte van die ontwikkeling van moraliteit. 
na iets so heerliks wat die Ryk kan word, / en U, U kan dit bring. Ek kan U dien" (Germanicus 1961:82).

En uiteindelik het Germanicus geen morele keuse nie. Germanicus kan immoraliteit nie ontsnap nie. Kies hy om getrou aan sy ideaal van suiwerheid en trou te bly ("Ek is getrou. Ek is aan trou gewoond" - Germanicus 1961:9) en Tiberius nie die slagoffer van verraad (daad $)$ te maak nie, tree hy ontrou (immoreel) teenoor die volk op. Sou hy die daad van geweld teenoor Tiberius pleeg, sou dit 'n morele verpligting wees wat hy ten opsigte van die Ryk en sy mense nakom - maar hy sou ontrou (immoreel) teenoor Tiberius optree - én teenoor sy eie aard. En hoe swaar weeg verraad gepleeg teenoor 'n keiser, en boonop nog 'n familielid? Vergelyk Figuur 1 hier onder wat onder andere Germanicus se verwantskap met Tiberius aandui, 'n kennisdomein (soos vroeër na verwys) wat toeligtend is ten opsigte van die konflik- en moraliteitsdilemma(s) wat Germanicus beleef.

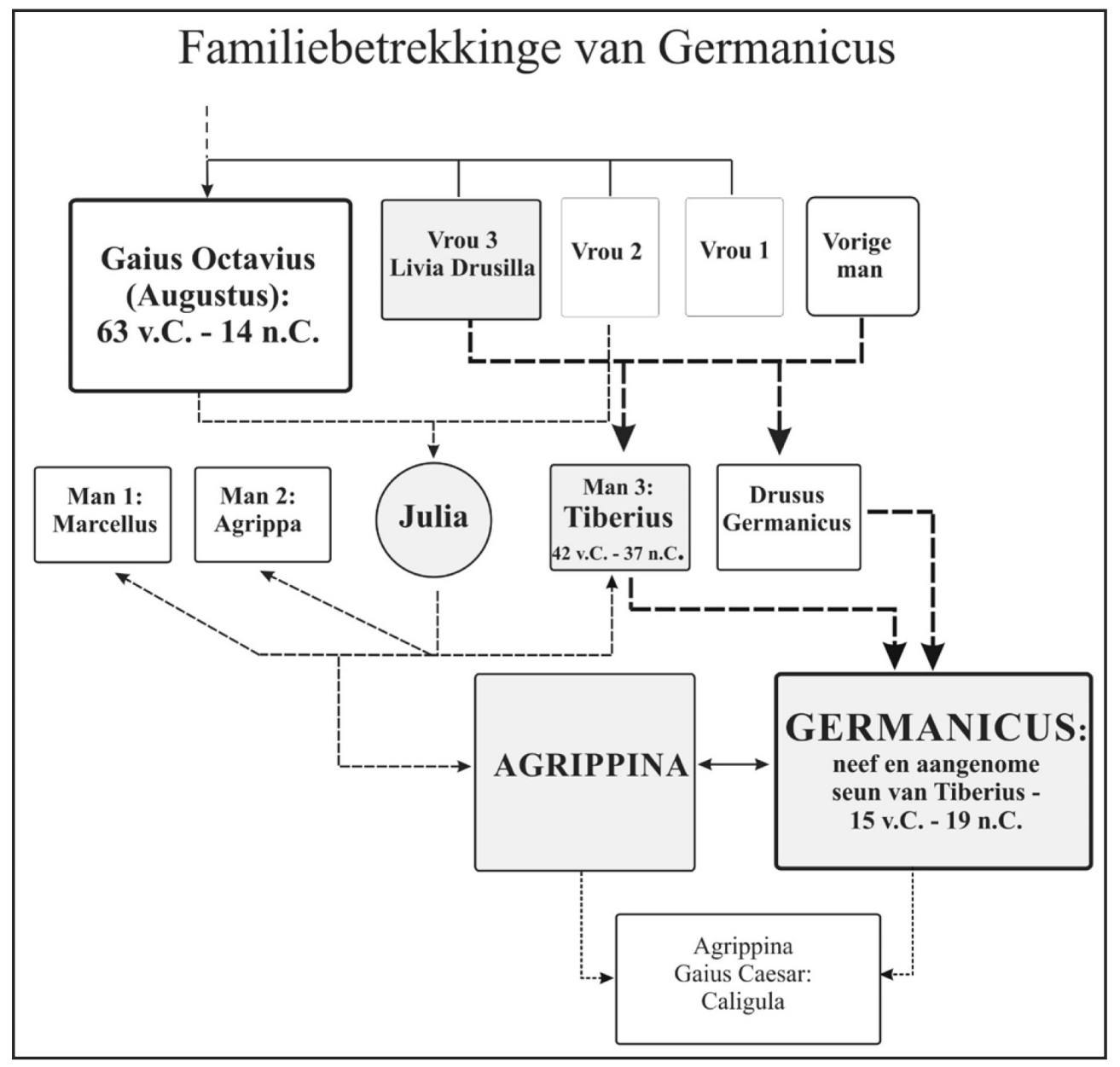

Figuur 1: $\quad$ Familiebetrekkinge van Germanicus 
Daarom word Germanicus uiteindelik self slagoffer, maar die instrument wat sy slagofferskap teweegbring, is (in sy eie woorde) nie Piso nie, nie Livia nie, ook nie Plancina nie - maar hy "sterf aan hierdie tyd" (Germanicus 1961:113). En "hierdie tyd" is 'n siek tyd, 'n immorele tyd - 'n tyd waarin "die heilige siekte ... ons almal / wat mens is (beet het); hy skeur, hy laat ons skreeu en raas" (Germanicus 1961:55), aldus Germanicus. Hierdie metaforiese beskrywing van dié besondere tyd is in ooreenstemming met Lakoff en Johnson (1999:291) se beskouing dat immoraliteit metafories dikwels as 'n aansteeklike siekte ervaar word. In hierdie woorde vind ons dus ook Germanicus se bekentenis van sy eie immoraliteit, omdat daar kragte is wat ook op die nie-sigbare vlak werksaam is (soos 'n siekte), wat hy self nie kan ontkom nie, maar ook nie kan bestry nie.

Die bestek van hierdie betoog laat nie 'n bespreking toe van al die kragte wat binne hierdie historiese drama 'n moraliteitsnetwerk struktureer nie. Cloete (1963:93) se beskouing dat die woord "self dramatiese figuur, handelingsmoment" in Germanicus word en dat die "karakters ... maklik agter hulle woorde (verdwyn)" sou 'n sinvolle vertrekpunt kon wees. Met betrekking tot Germanicus noem hy byvoorbeeld die sogenaamde "duistere of magswoorde", soos heers, heersersras, heersersreg, mag, krag, trots, vrees, haat, asook daad, wat met bepaalde adjektiewe gepaard gaan en as sodanig 'n soort "familiale bestaan" binne die versdrama voer.

\section{SLOTBESKOUING}

Uit die voorgaande bespreking het dit geblyk dat die substantief daad, as afgeleide vorm van die sogenaamde "leë" doen, 'n hele spektrum betekenisonderskeidings en gesubjektiveerde betekenisimplikasies kontekstueel binne sy bestek het.

Afgesien van die kontekstuele betekenisbegrensing van die betrokke daad-handeling geskied die keuse van die leksikale item daad (óf die implikasie van 'n daad-handeling) binne die Germanicus-konteks meestal op grond van 'n bepaalde moraliteitsoordeel. Daad word dan as 'n oordeelsnaamwoord gebruik, ten opsigte waarvan die gesubjektiveerde betekenisnuanse "moraliteit" binne die bepaalde konteks sy weg na die voorgrond vind. Sou daad slegs geïmpliseer word, word "moraliteit" 'n gesubjektiveerde oordeel in die konseptualisering van die onderhawige handeling.

In Van Wyk Louw se ander dramatiese werke is die verweefdheid van daad en moraliteit nie uitgesluit nie, egter nie op die skaal waarin dit neerslag vind in Germanicus nie. Insig en beoordeling ten opsigte van hierdie betrokke werke sou net baat kan vind indien hierdie verskynsel baie bewustelik in gedagte gehou word.

In opmerkings van prof. Jaap Steyn, soos vroeër in hierdie betoog na verwys is, noem hy dat Van Wyk Louw se 1952-besinning oor die aard van die daad waarskynlik onder andere betrekking gehad het op die Suid-Afrikaanse politiek van die jare veertig. Hiertoe kan tereg toegevoeg word dat die verskillende aspekte van die daad en die verweefdheid daarvan met verskillende dimensies van moraliteit nie beperk was tot antieke tye nie. Die universele relevansie daarvan ten opsigte van ander tye - en waarskynlik veral die huidige tydsgewrig, nasionaal en internasionaal - maak 'n herbekyk, herontleding en herbesinning van Van Wyk Louw se dramatiese werk uiters noodsaaklik.

\section{BIBLIOGRAFIE}

Antonissen, R. 1963. Kern en tooi. Kroniek van die Afrikaanse lettere 1951-1960. Kaapstad: Nasou. Austin, J.L. 1962. How to do things with words. Oxford: Clarendon Press. 
Boogaart, R., Lalleman, J., Mooijaart, M. \& Van der Wal, M. (redakteurs). 2009. Woorden wisselen. Leiden: SNL Leiden.

Botha, W.J. 1975. Die leë werkwoord in Afrikaans. Ongepubliseerde magisterverhandeling. Pretoria: Universiteit van Suid-Afrika.

Botha, W.J. 1991. Taalhandelingsdeterminante in die onderrig. S.A. Tydskrif vir Taalkunde, 9-1:24-29.

Botha, W.J. 2006. Die aard van die daad: wat doén Germanicus (nie) ... en waarom (nie)? Journal for Language Teaching / Tydskrif vir Taalonderrig, 40(1):164-177.

Botha, W.J. 2009a. Doen en die daad in Afrikaans. In Boogaart, R., Lalleman, J., Mooijaart. M. \& Van der Wal, M. (redakteurs). 2009. Woorden wisselen. Leiden: SNL Leiden, pp. 183-194.

Botha, W.J. 2009b. N.P. van Wyk Louw: krag, mag, moraliteit - en die daad. Ongepubliseerde N.P. van Wyk Louw-gedenklesing: Universiteit van Johannesburg.

Brink, A.P. 1966. Germanicus en Shakespeare. In Nienaber, P.J. (red.). 1966. Beeld van 'n digter. N.P. van Wyk Louw. Kaapstad: Nasionale Boekhandel, pp. 311-323.

Cloete, T.T. 1963. Op die woord af. Johannesburg, Port Elizabeth, Kaapstad, Bloemfontein: Nasionale Boekhandel.

Cloete, T.T. 1980. Van Wyk Louw se fundamenteel dramatiese instelling. Publikasiereeks van die Randse Afrikaanse Universiteit. A 126. Johannesburg: RAU.

Conradie, P.J. 1974. Die gebruik van antieke bronne in Van Wyk Louw se Germanicus. Spanning en ewewig. Pretoria, Kaapstad: Academica.

Dekker, G. 1963. Afrikaanse literatuurgeskiedenis. Kaapstad: Nasou.

Evans, V. \& Green, M. 2006. Cognitive linguistics. An introduction. Edinburgh: Edinburgh University Press.

Grové, A.P. 1965. Oordeel en vooroordeel. Kaapstad: Nasou.

Johnson, M. 1987. The body in the mind: The bodily basis of meaning, imagination and reason. Chicago: University of Chicago Press.

Labuschagne, F.J. \& Eksteen, L.C. 1992. Verklarende Afrikaanse woordeboek. Pretoria: Van Schaik (elektroniese uitgawe: Pharos woordeboeke).

Lakoff, G. \& Johnson, M. 1980. Metaphors we live by. Chicago: University of Chicago Press.

Lakoff, G. \& Johnson, M. 1999. Philosophy in the flesh. The embodied mind and its challenge to Western thought. New York: Basic Books.

Langacker, R.W. 1990. Subjectification. Cognitive Linguistics 1-1:5-38.

Langacker, R.W. 2004. A visit to cognitive grammar. In Francisco José Ruiz de Mendoza Ibáñez (ed.). Annual review of cognitive linguistics. Amsterdam: John Benjamins Publishing Company, pp. 305319.

Louw, N.P. van Wyk. 1956 (1961). Germanicus. Kaapstad: Nasionale Boekhandel.

Louw, N.P. van Wyk. 1986. Versamelde prosa 1. Kaapstad: Tafelberg-Uitgewers Beperk.

Microsoft. 2000. Microsoft Encarta Encyclopedia Delux 2000. Redmond: Microsoft (elektroniese weergawe).

Ponelis, F.A. 1978. Afrikaanse sintaksis. Pretoria: J.L. van Schaik.

Reichling, A. 1947. De Taal: haar wetten en haar wezen. In Ensie 1947, Ensie 2, Anton Reichling, S.J. \& J.S. Witsenelias. https://www.ensie.nl/ensie-1947/taal-haar-wetten-en-haar-wezen [12 September 2019].

Taylor, J.R. 2002. Cognitive grammar. Oxford: Oxford University Press.

Van Heerden, E. 1967. N.P. van Wyk Louw. Monografiee uit die Afrikaanse letterkunde Nommer 3. Elsiesrivier: Nasou.

Westen, D. 1996. Psychology. Mind, brain, \& culture. New York: John Wiley \& Sons. 